\title{
Drinking Water Analysis of Pokhale Village and Engineering Solutions for its Upgradation
}

\author{
Miss. Sneha Jayawantrao Sankpal ${ }^{1}$ \\ ${ }^{1}$ Environmental Science and Technology, \\ Department of Technology, Shivaji University, \\ Kolhapur, Maharashtra, 416004, India
}

\author{
Mr. B. R. Bagane ${ }^{3}$ \\ ${ }^{3}$ Department of Civil Engineering, \\ Tatyasaheb Kore Institute of Engineering and Technology, \\ Warananagar, Maharashtra, 416113, India
}

\author{
Mr. G. S. Kulkarni ${ }^{2}$ \\ ${ }^{2}$ Shivaji University, \\ Kolhapur, \\ Maharashtra, 416004, India
}

\begin{abstract}
Unsafe and inadequate supply of potable water is serious issue in developing nations. So this research work was undertaken to explore the quality as well as quantity of various water sources used for drinking in Pokhale village. After surveying, a total six sample stations were selected from different locations where large number of individuals were utilizing them to drink. It is found that, this village depends upon public pipe born water supply, boreholes and open wells for drinking purpose and all the zones have access to adequate water supply. The collection of samples were done in pre-monsoon as well as post-monsoon season and tested for various physical, chemical and microbial properties such as temperature, pH, electrical conductance, turbidity, total dissolved solid, total hardness, total alkalinity, sulphate, nitrate, phosphate, potassium, chloride and total coliform. Analysis was done by using standard procedures (APHA/NEERI) and result values compared with the World Health Organisation (WHO) guideline values. Most of the parameters were well within WHO guideline values for all the six samples, except that higher level of turbidity and minimum but exceeding MPN was recorded at all sampling sites. Hence from the present research, it is realized that, drinking water sources are suitable or not for human health. From these results, suggestions are given for obtaining clean drinking water in Pokhale village.
\end{abstract}

Keywords: Water quality analysis, quantitative analysis, drinking water, parameters, upgradation, treatment units.

\section{INTRODUCTION}

Environmental pollution is the worldwide issue of the day. The growth of industrial region is speedy and very fast, therefore associated anthropogenic activities such as waste discharge from industries, transportation and domestic activities have also been increased. The domestic waste generated is directly comes in contact with different sites of water sources without any treatment. Also the continuous flow of wastewater from agricultural area contaminates the water source of surrounding area. This entire problem impacts the water sources and ultimately human health. Water is one of the three primary components of the surroundings. It is almost valuable and crucial natural resources. Therefore, there exists a near linkage between the water quality and the environment which bears a nearly significance for ecosystem.

Water is fundamental in the life of every single living organism including simple plants, microorganisms to most complicated living framework referred to as human body. It is a mixture of oxygen plus hydrogen atoms, having chemical formulation as $\mathrm{H}_{2} \mathrm{O}$ and acknowledged to be the most plentiful compound on surface of earth. Also it is significant because of its distinctive physical and chemical characteristics.

Water covers approximately $80 \%$ of earth's surface. Out of this whole amount of water, approximately $97 \%$ of earth's water resources include water from seas and oceans. But it is extremely saline for drinking and also for direct usage in industrial, farming activities. Also in polar icecaps and giant glaciers, up to $2.4 \%$ of water is trapped. Therefore not even $1 \%$ amount of water is accessible for consuming, domestic, farming and industrial utilization. Because of expanding industrialization as well as exploding populace, the water supply demand has additionally been growing extraordinarily. Inadequate supply of water is still one of the major problem in some regions. Hence, the safe water supply with quality as well as adequate amount is of essential importance for the human being's welfare.

Availability to secure potable water is essential for sustainable development as well as for the production of food, high-quality fitness and reduction in poverty. Also, it is important for existence and adequate supply of safe water should be made accessible to people. Water is therefore turning into an important factor for improvement and standard of life in several nations. Thus, water supposed for human utilization should be free from germs, pathogen, or any hazardous chemicals; since water infected with microorganisms is reason for epidemics. It means ideal potable water isn't a luxurious however most necessary need of existence itself. The WHO discovered that, $75 \%$ of all illnesses in developing nations are due to contaminated consuming water. Hence, worries about water quality are frequently the most significant factor for determining accessibility to water from the better sources. 
The suitability of potable water is shown by acceptable quality by using its physico-chemical and microbial properties. Various parameters have been proposed by many local and international agencies to evaluate bacteriological and physico-chemical nature of consuming water.

Most common issues found in household water supply systems can be due to iron, sodium, alkalinity, sulfides, chloride, hardness, acidity, and also illnesscausing pathogens, for example, viruses as well as bacteria. A primary concern about the individuals living in developing countries is that of getting clean drinking water. Most people in rural areas rely upon ground and surface water for sustenance. The situation is not different in Pokhale village. As the Pokhale village is dependent on various water sources for drinking purpose, it is necessary to evaluate water quality and to decide either it is fit for consumption or not. The present investigation was undertaken to estimate the various water quality parameters and to check it either it is suitable for human health or not.

\section{OBJECTIVES}

The primarily goal of the present research work is to assess the various sources of drinking water in Pokhale village.

Specifically, this study seeks:

1. To analyze the quality as well as quantity of drinking water from the various sources in Pokhale village.

2. To determine the degrees of some physico-chemical and microbial characteristics of water.

3. To compare the various parameters with World Health Organization (WHO) guideline values.
4. To determine either drinking water sources are fit for consumption or not.

5. To suggest improvements for the identified problems.

\section{MATERIALS AND METHODS}

\subsection{General Description of Study Area:}

Pokhale village is situated in Panhala taluka of Kolhapur district in Maharashtra state, India. It has place with Desh or Paschim Maharashtra region with latitude 16.846572 and longitude 74.18734. Total geographical area of Pokhale village is 378.25 hectares. The village is situated on the Warana river basin. The climate of Pokhale is mostly tropical. Summer month is comparatively cooler, but much more humid than neighbouring inland cities.

\subsection{Field Work:}

It included the important data collected through oral interview with people in Grampanchayat and different zones of the village.

\subsection{Zoning of the Study Area, Interview and Site Observation Assessment:}

The Pokhale village was partitioned into three zones with the help of main road network as shown in Figure 3.3, as Zone 1, Zone 2 and Zone 3. These zones of the examination area had been visited for on-spot evaluation of water supply sources and also oral interview had been conducted with occupants to find out the different resources of water supply accessible to them, recurrence of supply, availability and the nature of water supply.

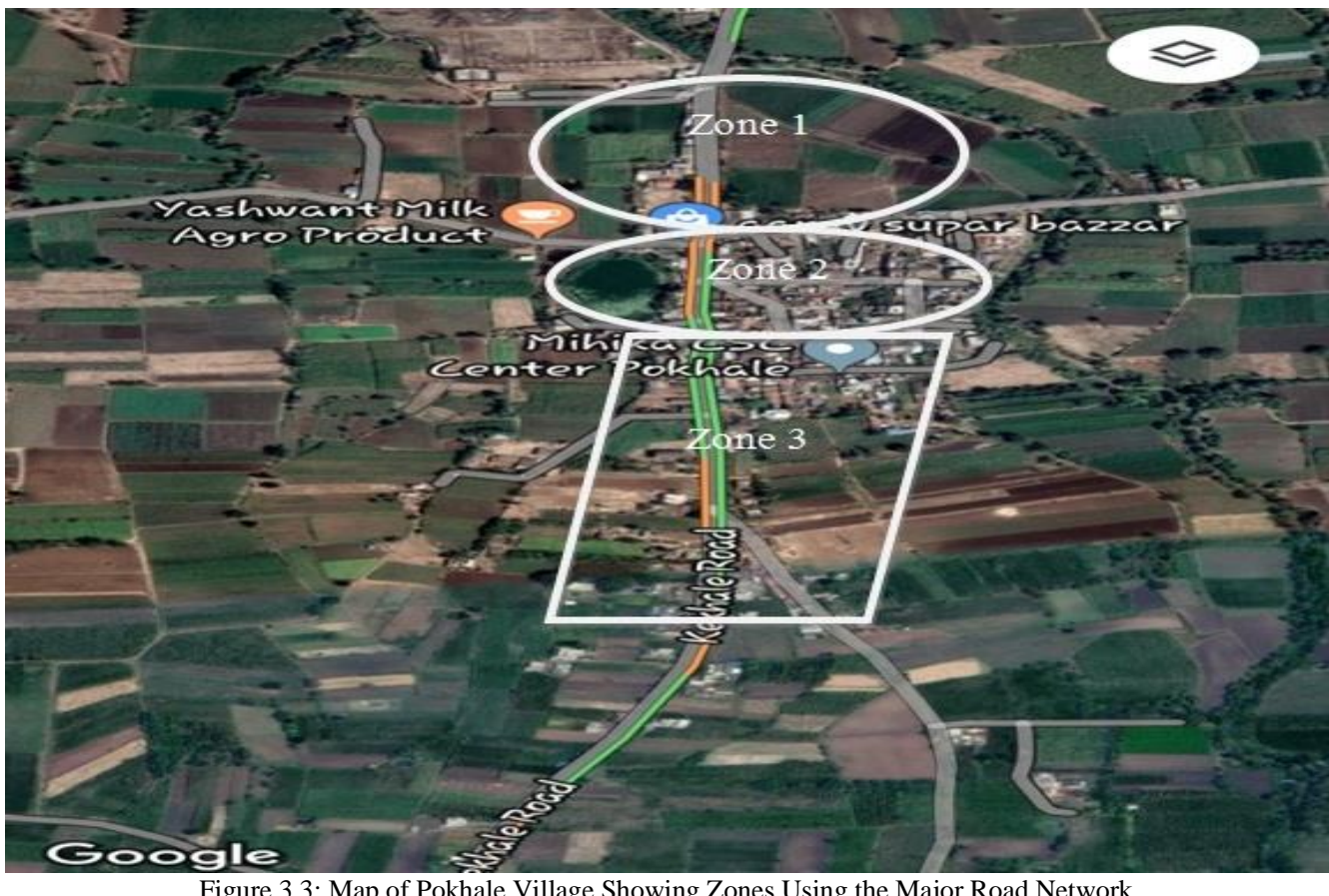

\subsection{Estimating Water Availability from Open Well:}

The open wells in the village are pumped through motor, the water availability per day during post-monsoon and pre-monsoon season was estimated based on water discharge rate of pump and range of hours of operation of pump per day. For this, information collected at respective sites. 


\subsection{Collection of Sample:}

In the present investigation, total 6 water samples from drinking water sources in Pokhale village namely, two samples from open well, three from bore well and one from piped river water were collected. Selection of six different stations were identified based on importance of the source, where most of the people were utilizing them for consuming reason. All the water samples were taken from the respective site during pre-monsoon (April 2019) as well as post-monsoon season (December 2018) for testing in cleaned plastic polyethylene bottles of 1liter between 10.00 a.m.-11:30 a.m. For bacteriological examination, samples were taken in sterilized bottles. The water sampling collection, methods as well as strategy were done as per standards set down.

Table 3.5: Details of the Sources from which Samples Collected

\begin{tabular}{|c|c|c|c|c|c|}
\hline \multirow{2}{*}{$\begin{array}{l}\text { Sr. } \\
\text { No. }\end{array}$} & \multirow{2}{*}{ Sources } & \multirow{2}{*}{$\begin{array}{l}\text { Sample } \\
\text { Coding }\end{array}$} & \multirow{2}{*}{ Location } & \multicolumn{2}{|c|}{ Coordinate } \\
\hline & & & & Easting & Northing \\
\hline 1 & Open Well & Sample A & Near Kekhale Road & $74^{0} 10^{\prime} 55^{\prime \prime}$ & $16^{0} 50^{\prime 2} 25^{\prime \prime}$ \\
\hline 2 & Open Well & Sample B & Near Stream & $74^{0} 11^{\prime} 21^{\prime \prime}$ & $16^{0} 50^{\prime} 43^{\prime \prime}$ \\
\hline 3 & Private Borehole & Sample C & Biradev nagar & $74^{0} 11^{\prime} 12^{\prime \prime}$ & $16^{0} 5020 "$ \\
\hline 4 & Piped River Water & Sample D & Biradev nagar & $74^{0} 11^{\prime} 13^{\prime \prime}$ & $16^{0} 50^{\prime} 24^{\prime \prime}$ \\
\hline 5 & Private Borehole & Sample E & Near Lake & $74^{0} 11^{\prime} 13^{\prime \prime}$ & $16^{0} 50^{\prime} 43^{\prime \prime}$ \\
\hline 6 & Private Borehole & Sample F & Bhagatsing Galli & $74^{0} 11^{\prime} 18^{\prime \prime}$ & $16^{0} 50 \times 47^{\prime \prime}$ \\
\hline
\end{tabular}

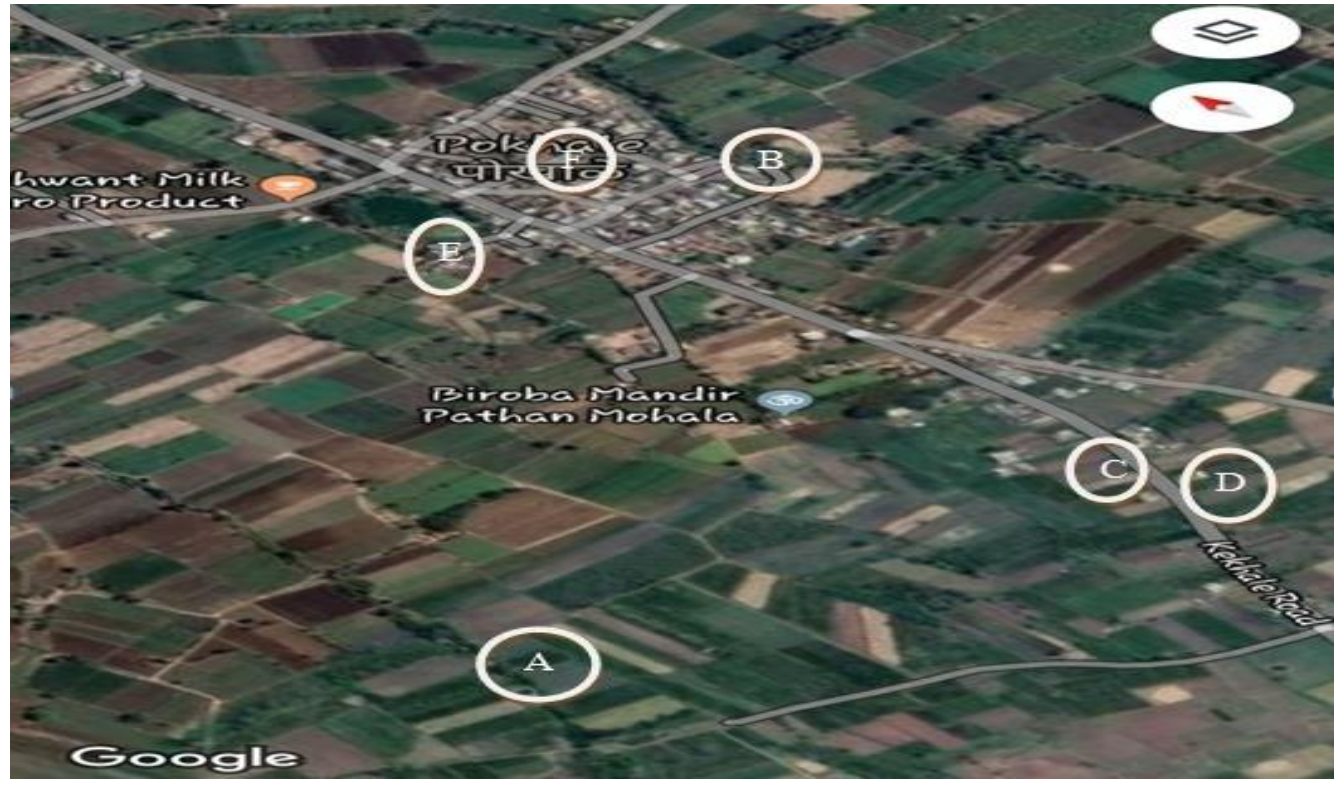

Figure 3.5: Map of Pokhale Showing Sources and Location of Sample Collected

\subsection{Laboratory Analysis:}

After collecting water samples, they were brought into the laboratories for evaluation of physical (turbidity, total dissolved solids and electrical conductivity), chemical $(\mathrm{pH}$, total alkalinity, total hardness, chlorides, potassium, phosphate, nitrate, and sulphate) as well as microbiological properties (total coliform). Water temperature was determined during sample collection at sampling sites. The water quality parameters were analyzed by using standard procedures recommended by Standard methods for the examination of water and wastewater, American Public Health Association, 22 ${ }^{\text {nd }}$ edition, 2012 and NEERI, Manual on Water and Wastewater Analysis.

\section{RESULTS AND DISCUSSION}

\subsection{Quantitative Analysis:}

The different sources of consuming water in Pokhale village are as shown in Table 4.1.1.

Table 4.1.1: Different Drinking Water Sources Used in Pokhale Village

\begin{tabular}{|c|c|c|c|c|}
\hline Zone & Location & Primary Source & Secondary Source & Remarks \\
\hline \multirow{3}{*}{ One } & Bahirewadi Road & Household piped water & Borehole & Intermittent water supply \\
\cline { 2 - 5 } & Bhagatsing Galli & Household piped water & Borehole & Intermittent water supply \\
\cline { 2 - 5 } & $\begin{array}{c}\text { Main Road (Spring to } \\
\text { Bhagatsing chouk) }\end{array}$ & Household piped water & Borehole, Open well & Intermittent water supply \\
\hline \multirow{3}{*}{ Two } & Naik Galli & Household piped water & Borehole & Intermittent water supply \\
\cline { 2 - 5 } & Patil Galli & Household piped water & Open well & Intermittent water supply \\
\cline { 2 - 5 } & $\begin{array}{c}\text { Main Road (Bhagatsing chouk } \\
\text { to Police Patil Galli) }\end{array}$ & Household piped water & Borehole & Intermittent water supply \\
\hline \multirow{2}{*}{ Three } & Police Patil Galli and main road & Household piped water & Borehole, Open well & Intermittent water supply \\
\cline { 2 - 5 } & Biradev nagar & Household piped water & Borehole, Open well & Intermittent water supply \\
\hline
\end{tabular}


The total water availability per day for different sources is represented in Table 4.1.2 as below:

Table 4.1.2: Estimating Water Availability from Open Well

\begin{tabular}{|c|c|c|c|c|}
\hline Season & Open Well & $\begin{array}{l}\text { Discharge rate of water } \\
\text { (litres/min) }\end{array}$ & $\begin{array}{l}\text { Average hours of pumping } \\
\text { in a day }\end{array}$ & Total water availability (litres/ day) \\
\hline \multirow[t]{3}{*}{ Post-Monsoon } & A & 500 & 10 & 300000 \\
\hline & $\mathrm{B}$ & 300 & 5 & 45000 \\
\hline & \multicolumn{3}{|c|}{ Total Availability } & 345000 \\
\hline \multirow[t]{3}{*}{ Pre-Monsoon } & $\mathrm{A}$ & 500 & 5 & 150000 \\
\hline & $\mathrm{B}$ & 300 & 2 & 36000 \\
\hline & \multicolumn{3}{|c|}{ Total Availability } & 186000 \\
\hline
\end{tabular}

\subsection{Physico-Chemical Analysis:}

The experimental results of various physico-chemical parameters for water samples are presented in Table 4.2.1 and Table 4.2.2:

Table 4.2.1: Physico-Chemical Analysis of Different Samples during Post-Monsoon Season

\begin{tabular}{|c|c|c|c|c|c|c|}
\hline \multirow[t]{2}{*}{ Parameter Studied } & \multicolumn{6}{|c|}{ Sample Code } \\
\hline & Sample A & Sample B & Sample C & Sample D & Sample E & Sample F \\
\hline Temperature & 21 & 19.5 & 20 & 20.5 & 21 & 20 \\
\hline Turbidity & 38.7 & 74.5 & 34.8 & 54 & 17 & 28 \\
\hline EC & 416 & 892 & 585 & 218 & 552 & 435 \\
\hline TDS & 264.6 & 487.3 & 379.6 & 132.4 & 320 & 267 \\
\hline $\mathrm{pH}$ & 7.82 & 8.2 & 6.72 & 7.34 & 7.11 & 7.18 \\
\hline $\mathrm{TH}$ & 146 & 334 & 264 & 97 & 318 & 275 \\
\hline Chloride & 29.07 & 132.8 & 83.6 & 21.10 & 50 & 52.4 \\
\hline Alkalinity & 108 & 79 & 72 & 51 & 46 & 63 \\
\hline Potassium & 0.33 & 5.3 & 0.27 & 0.41 & 0.28 & 0.39 \\
\hline Nitrate & 1.68 & 1.85 & 1.18 & 1.26 & 1.20 & 1.29 \\
\hline Phosphate & 0.32 & 0.94 & 0.71 & 0.46 & 0.97 & 0.88 \\
\hline Sulphate & 66.5 & 75.20 & 55 & 50.30 & 62.80 & 59.70 \\
\hline
\end{tabular}

Table 4.2.2: Physico-Chemical Analysis of Different Samples during Pre-Monsoon Season

\begin{tabular}{|c|c|c|c|c|c|c|}
\hline \multirow[t]{2}{*}{ Parameter Studied } & \multicolumn{6}{|c|}{ Sample Code } \\
\hline & Sample A & Sample B & Sample C & Sample D & Sample E & Sample F \\
\hline Temperature & 23 & 22 & 21.5 & 22 & 22.5 & 22 \\
\hline Turbidity & 36.4 & 67 & 40 & 41.6 & 14 & 30.6 \\
\hline $\mathrm{EC}$ & 330 & 1000 & 610 & 240 & 570 & 427 \\
\hline TDS & 222.8 & 527.5 & 412.4 & 124.8 & 356 & 284 \\
\hline $\mathrm{pH}$ & 7.24 & 7.54 & 6.85 & 6.87 & 6.92 & 7.13 \\
\hline TH & 150 & 250 & 300 & 90 & 295 & 280 \\
\hline Chloride & 25.3 & 125.14 & 65.07 & 15.02 & 57 & 43.7 \\
\hline Alkalinity & 82 & 66 & 49 & 24 & 38 & 71 \\
\hline Potassium & 0.34 & 7.99 & 0.30 & 0.46 & 0.31 & 0.43 \\
\hline Nitrate & 1.71 & 1.93 & 1.20 & 1.32 & 1.28 & 1.33 \\
\hline Phosphate & 0.57 & 1.36 & 1.13 & 0.89 & 1.08 & 1.15 \\
\hline Sulphate & 71.70 & 78.20 & 54.03 & 53.80 & 60 & 66.40 \\
\hline
\end{tabular}

\subsection{Microbial Analysis:}

The experimental results for microbial parameter of water samples are represented in Table 4.3.1 and Table 4.3.2:

Table 4.3.1: Microbial Analysis of Different Samples During Post-Monsoon Season

\begin{tabular}{|c|c|c|c|c|c|c|}
\hline \multirow{2}{*}{ Parameter Studied } & \multicolumn{7}{|c|}{ Sample Code } & Sample D & Sample E & Sample F \\
\cline { 2 - 7 } & Sample A & Sample B & Sample C & 23 & 15 & 14 \\
\hline Total coliform & 7 & 15 & 10 & \multicolumn{1}{c|}{${ }^{2}$}
\end{tabular}

Table 4.3.2: Microbial Analysis of Different Samples during Pre-Monsoon Season

\begin{tabular}{|c|c|c|c|c|c|c|}
\hline Parameter Studied & \multicolumn{7}{c|}{ Sample Code } \\
\cline { 2 - 7 } & Sample A & Sample B & Sample C & Sample D & Sample E & Sample F \\
\hline Total coliform & 12 & 18 & 9 & 19 & 11 & 12 \\
\hline
\end{tabular}

\subsection{Comparison between seasonal variation for physical, chemical, microbial characteristics of different water samples and WHO standards:}

The range of physico-chemical and microbial parameters of different samples for the post-monsoon and pre-monsoon season are given in Table 4.4 and compared with WHO standards. 
Table 4.4: Comparison of Physico-Chemical, Microbial Parameters with WHO Standards

\begin{tabular}{|c|c|c|c|c|c|}
\hline \multirow{2}{*}{ Sr. No. } & \multirow{2}{*}{ Parameters } & \multirow{2}{*}{ Unit } & \multicolumn{2}{|c|}{ Result } & \multirow{2}{*}{$\begin{array}{c}\text { WHO } \\
\text { Standards } \\
\text { (Range) }\end{array}$} \\
\hline & & & Post-monsoon season & Pre-monsoon season & \\
\hline 1. & Temperature & ${ }^{0} \mathrm{C}$ & $19.5-21$ & $21.5-23$ & - \\
\hline 2. & Turbidity & NTU & $17.0-74.5$ & $14-67$ & 5 \\
\hline 3. & EC & $\mu \mathrm{S} / \mathrm{cm}$ & $218-892$ & $240-1000$ & - \\
\hline 4. & TDS & $\mathrm{mg} / \mathrm{L}$ & $132.4-487.3$ & $124.8-527.5$ & 500 \\
\hline 5. & $\mathrm{pH}$ & - & $6.72-8.20$ & $6.85-7.54$ & $6.5-8.5$ \\
\hline 6. & $\mathrm{TH}$ & $\mathrm{mg} / \mathrm{L}$ & $97.0-334.0$ & $90.0-300.0$ & 500 \\
\hline 7. & Chloride & $\mathrm{mg} / \mathrm{L}$ & $21.10-132.8$ & $15.02-125.14$ & 250 \\
\hline 8. & Alkalinity & $\mathrm{mg} / \mathrm{L}$ & $46.0-108.0$ & $24.0-82.0$ & - \\
\hline 9. & Potassium & $\mathrm{mg} / \mathrm{L}$ & $0.27-5.30$ & $0.30-7.99$ & 30 \\
\hline 10. & Nitrate & $\mathrm{mg} / \mathrm{L}$ & $1.18-1.85$ & $1.20-1.93$ & 50 \\
\hline 11. & Phosphate & $\mathrm{mg} / \mathrm{L}$ & $0.32-0.94$ & $0.57-1.36$ & - \\
\hline 12. & Sulphate & $\mathrm{mg} / \mathrm{L}$ & $50.30-75.20$ & $53.8-78.20$ & 250 \\
\hline 13. & Total coliform & MPN/100 mL & $7-23$ & $9-19$ & 0 \\
\hline
\end{tabular}

\section{SOLUTION FOR UPGRADATION IN EXISTING SYSTEM}

To improve the quality of drinking water, it is necessary to provide some treatment units. By considering the design period of 30 years, the population at the end of design period (2051) is calculated as 3500, by using different methods of Population Forecasting. As per this, the total water demand in 2051 will raise to 1.3 MLD. By considering the results of water quality, following treatment units will be suggested to provide.

The decadal population data for Pokhale village is presented as below in Table 5:

Table 5: Decadal Population

\begin{tabular}{|c|c|c|}
\hline Sr. No. & Year & Census Population \\
\hline $\mathbf{1}$ & 1951 & 953 \\
\hline $\mathbf{2}$ & 1961 & 1103 \\
\hline $\mathbf{3}$ & 1971 & 1290 \\
\hline $\mathbf{4}$ & 1981 & 1495 \\
\hline $\mathbf{5}$ & 1991 & 1762 \\
\hline $\mathbf{6}$ & 2001 & 2065 \\
\hline $\mathbf{7}$ & 2011 & 2274 \\
\hline
\end{tabular}

\section{Suggested Units of Treatment Plant:}

$>$ Flash mixer

$>$ Coagulant dose

$>$ Sedimentation cum flocculation tank

$>$ Rapid sand filter

$>$ Chlorination unit

\subsection{Design of Mechanical Flash Mixer:}

\begin{tabular}{|l|l|l|}
\hline 1. & Design flow & $1.3 \mathrm{MLD}$ \\
\hline 2. & Detention time & 60 second \\
\hline 3. & Depth of tank (free board $0.2 \mathrm{~m})$ & $1.7 \mathrm{~m}$ \\
\hline 4. & Power required & 144.48 watt \\
\hline 5. & Diameter of impeller & $0.4 \mathrm{~m}$ \\
\hline 6. & Number of blade $(0.5 \mathrm{~m} \times 0.5 \mathrm{~m})$ & 6 \\
\hline 7. & Diameter of inlet and outlet pipes & $200 \mathrm{~mm}$ \\
\hline
\end{tabular}

\subsection{Alum Dose:}

\begin{tabular}{|l|l|l|}
\hline 1. & Peak alum dose & $50 \mathrm{~m} / \mathrm{L}$ \\
\hline 2. & Strength of solution & $5 \%$ \\
\hline 3. & Number of tanks & 2 \\
\hline 4. & Rating of each tank & 12 hours \\
\hline 5. & Capacity of each tank & 1000 liter \\
\hline
\end{tabular}

\subsection{Design of Sedimentation cum Flocculation Tank:}

\begin{tabular}{|l|l|l|}
\hline 1. & Detention period & 2.6 hours \\
\hline 2. & Effective depth of water & $3.0 \mathrm{~m}$ \\
\hline 3. & Water wastage in desludging & $2 \%$ \\
\hline 4. & Size of tank (free board $0.5 \mathrm{~m})$ & $12 \mathrm{~m} \times 4 \mathrm{~m} \times 3.5 \mathrm{~m}$ \\
\hline 5. & Longitudinal slope & 1 in 50 \\
\hline 6. & Side slope & 1 in 30 \\
\hline 7. & Size of floc chamber & $2.6 \mathrm{~m} \times 4 \mathrm{~m} \times 1.8 \mathrm{~m}$ \\
\hline 8. & Diameter of outlet pipe & $200 \mathrm{~mm}$ \\
\hline 9. & Diameter of overflow pipe & $250 \mathrm{~mm}$ \\
\hline
\end{tabular}




\subsection{Design of Rapid Gravity Filter:}

\begin{tabular}{|l|l|l|}
\hline 1. & Number of filter units & 2 \\
\hline 2. & Size of filter unit & $3.7 \mathrm{~m} \mathrm{x} 2.9 \mathrm{~m}$ \\
\hline 3. & Sand bed depth & $60 \mathrm{~cm}$ \\
\hline 4. & Depth of gravel & $50 \mathrm{~cm}$ \\
\hline 5. & Spacing for laterals & $15 \mathrm{~cm}$ \\
\hline 6. & Number of laterals on both sides of manifold & 50 \\
\hline 7. & Diameter of lateral & $25 \mathrm{~mm}$ \\
\hline 8. & Number of perforations per lateral & 11 \\
\hline 9. & Diameter of perforations & $9 \mathrm{~mm}$ \\
\hline 10. & Diameter of central manifold & $500 \mathrm{~mm}$ \\
\hline 11. & Number of troughs & 2 \\
\hline 12. & Size of troughs (free board 0.1 m) & $0.3 \mathrm{~m} \times 0.36 \mathrm{~m}$ \\
\hline 13. & Total depth of filter box & $3.7 \mathrm{~m}$ \\
\hline 14. & Wash water pump power required & $1.77 \mathrm{~kW}$ \\
\hline 15. & Diameter of rising main & $100 \mathrm{~mm}$ \\
\hline 16. & Size of wash water tank (free board of $0.5 \mathrm{~m})$ & $4.7 \mathrm{~m} \times 4.7 \times 3.5 \mathrm{~m}$ \\
\hline
\end{tabular}

\subsection{Design of Chlorinator:}

\begin{tabular}{|l|l|l|}
\hline 1. & Maximum dose of free chlorine & $3 \mathrm{mg} / \mathrm{L}$ \\
\hline 2. & Available chlorine & $25 \%$ \\
\hline 3. & Strength of solution & $5 \%$ \\
\hline 4. & Quantity of chlorine required per day & $13 \mathrm{Kg} / \mathrm{Day}$ \\
\hline 5. & Capacity of tank & 350 liter \\
\hline 6. & Number of tank & 2 \\
\hline
\end{tabular}

\section{CONCLUSION}

This research work probed into the analysis of different drinking water sources in Pokhale village. From the results of this study, the following conclusions were drawn:

1. Household water supply (pipe born water) system represented the most widely used source of drinking water and each zones of the village have approach to piped water through water supply scheme. Also most of the people have their private boreholes/ tube wells.

2. $100 \%$ of the quantity of consuming water demanded by the occupants is met through local water supply sources in post-monsoon season as well as $85 \%$ in premonsoon season.

3. In pre-monsoon season, when water supply through local sources becomes inadequate, irrigation water supply scheme is used. Thus, the drinking water supply to Pokhale village is adequate.

4. The examination of chemical, physical and microbial parameters of six different water sources shows that, the levels of electrical conductance, total dissolved solids, $\mathrm{pH}$, total hardness, total alkalinity, chloride, potassium, phosphate, nitrate, and sulphate are well within the WHO guideline values except turbidity and total coliform.

5. That is most of the parameters are within the standard limits while minimum values of MPN and higher turbidity values are found for all the water sources. Hence, the drinking water sources in the Pokhale village are secure for drinking purpose but needs some treatment to minimize turbidity and microbial contamination.

\section{Suggestions/Recommendations:}

Through this research work, some suggestions are given for sustainable water quality:
1. For water supply scheme, treatment units such as alum for coagulation, rapid gravity filter, and chlorination can be used. Alternatives such as reverse osmosis, pressure filter, etc. can be used.

2. At household levels, the utilization of filtered water, alum and boiled water for consuming ought to be supported.

3. By educating the people about harmful effects of direct disposal of waste into or near water sources, contamination can be minimized.

\section{REFERENCES}

[1] Abdulrasoul Al-Omran, Fahad Al-Barakah, Abdullah Altuquq, Anwar Aly and Mahmoud Nadeem, "Drinking water quality assessment and water quality index of Riyadh, Saudi Arabia", Water Quality Research Journal of Canada - August 2015, vol 46 No.1 2011

[2] Amanial Haile Reda, "Physico-Chemical Analysis of Drinking Water Quality of Arbaminch Town”, Journal of Environmental \& Analytical Toxicology, Volume 6, Issue 2, 1000356

[3] APHA (22 ${ }^{\text {nd }}$ edition), "Standard methods for the examination of water and wastewater", American Public Health Association, Washington, DC (2012).

[4] Aryal J, Gautam B, Sapkota N, "Drinking Water Quality Assessment", J Nepal Health Res Counc, 2012 Sep;10(22):192-6

[5] Birdie J.S., "Water supply and sanitary engineering", Dhanpat Rai and Sons, New Delhi, 1994.

[6] Garg S.K., "Water supply engineering", Khanna publications, New Delhi, 1994.

[7] K. Soticha, Y. Jareeya, K. Sudjit, and P. Prapat, "Assessing Water Quality of Rural Water Supply in Thailand" Journal of Clean Energy Technologies, Vol. 2, No. 3, July 2014

[8] NEERI, "Manual on Water and Waste Water Analysis", National Environmental Engineering Research Institute (NEERI), Nagpur (1996).

[9] Olanipekun E.A., "Quantitative and Qualitative Assessment of Drinking Water Sources in Ile-Ife and Environs", American Journal of Engineering Research (AJER), e-ISSN: 2320-0847 pISSN: 2320-0936 Volume-3, Issue-8, pp-90-100 
[10] P. Pavendan, S. Anbu selvan and C. Sebastian rajasekaran, "Physico Chemical and microbial assessment of drinking water from different water sources of Tiruchirappalli District, South India", European Journal of Experimental Biology, 2011, 1 (1):183-189

[11] Pratiksha Tambekar, Pravin Morey, R. J. Batra and R. G. Weginwar, "Quality assessment of drinking water: A case study of Chandrapur District (M.S.)", Journal of Chemical and Pharmaceutical Research, 2012, 4(5):2564-2570, ISSN: 09757384

[12] Rajkamal R., Muthu Kumar, Madhan Raj, Muthu Rajesh, Jaya Kiruthiga, Joy Bazroy, " Assessment of water quality standards in the villages of Kanchipuram district, Tamil Nadu, India”, International Journal of Community Medicine and Public Health, pISSN 2394-6032 eISSN 2394-6040

[13] Tahera Akter, Fatema Tuz Jhohura, Fahmida Akter, Tridib Roy Chowdhury, Sabuj Kanti Mistry, Digbijoy Dey, Milan Kanti Barua, MdAkramul Islam and Mahfuzar Rahman, "Water Quality Index for measuring drinking water quality in rural Bangladesh: a cross-sectional study", Journal of Health, Population and Nutrition (2016) 35:4

[14] Tsega N, Sahile S, Kibret M, Abera B, "Bacteriological and physico-chemical quality of drinking water sources in a rural community of Ethiopia”, African Health Sciences 2013; 13(4): 1156- 1161

[15] World Health Organization, "Guidelines for Drinking Water quality", (fourth edition), Geneva, (2011).

[16] World Health Organization, Guidelines for Drinking Water quality, $3^{\text {rd }}$ edition, incorporating the $1^{\text {st }}$ and $2^{\text {nd }}$ Addenda, (2008).

[17] World Health Organization, "Guidelines for Drinking Water quality”, (Third edition), Geneva, (2004). 